\title{
Is GLUT2 required for glucose sensing?
}

\author{
F. C. Schuit \\ D epartment of B iochemistry, D iabetes R esearch C entre, V rije U niversiteit B russel, B russels, B elgium
}

The glucose transporter G L U T2 has been the subject of intensive research since it was cloned from a rat liver CD NA library [1]. A substantial amount of information has accumulated both in favour of and against the idea that GLUT2 plays an essential role in glucose sensing by pancreatic islets, a crucial process for insulin release and glucose homeostasis and one that may be disturbed in non-insulin-dependent diabetes mellitus (NID D M ) (reviewed in [2, 3]). This For D ebate paper does not discuss the whole literature on islet G LUT2, but rather focuses on some new developments in the field, among which are studies on G L U T 2 expression in human islet cells $[4,5]$ and the potential role of glucose transporters and glucokinase in rat alpha cells [6].

\section{G lucose sensing in beta cells}

Several lines of investigation have shown that glucose-induced signalling in rat or mouse beta cells involves metabolism of the sugar [7, 8]. In vitro studies with the perfused rat pancreas [9] or isolated islets [10] provided the first links between glucose metabolism and insulin release. They showed that the potency of different carbohydrates to induce insulin release correlates well with the efficiency at which the particular sugar is metabolised, glucose and mannose being good secretagogues while the non-metabolisable sugars 3-0-methyl glucose (3-O M G) or desoxyglucose fail to induce secretion [11]. In agreement with this idea, mannoheptulose and glucosamine, two inhibitors of glycolysis at the level of glucose

Corresponding author: Dr. F.C. Schuit, Department of Biochemistry, D iabetes $R$ esearch Centre, $V$ rije U niversiteit B russel, L aarbeeklaan 103, B-1090 B russels, B elgium

A bbreviations: NID D M , N on-insulin-dependent diabetes mellitus; 3-O M G, 3-O -methyl glucose. phosphorylation, blocked glucose-induced insulin release [12]. G lucose metabolism, causing a rise in cytosolic [A TP ]/[A D P] ratio, closes A TP-dependent $K^{+}$channels [13], inducing membrane depolarisation and influx of $\mathrm{Ca}^{2+}$, which in turn is believed to induce allosteric interactions or phosphorylation of proteins involved in exocytosis. The dose-response curves of glucose-induced metabolism, ionic fluxes and insulin release exhibit similar substrate sensitivity and responsiveness [14].

This last feature is essential from a physiological standpoint, since normal beta cells are able to discriminate between basal glycaemia ( 3 to $5 \mathrm{mmol} / \mathrm{l}$ ) and postprandial glucose levels of around $10 \mathrm{mmol} / \mathrm{l}$. Such discrimination requires high- $\mathrm{K}_{m}$ glucose metabolism, i. e. a process which proceeds at very low rates at $3 \mathrm{mmol} / \mathrm{l}$ glucose, and which accelerates above $5 \mathrm{mmol} / \mathrm{l}$ substrate. In contrast, most other tissues start glycolysis with low- $\mathrm{K}_{m}$ hexokinases which are fully saturated at $1 \mathrm{mmol} / \mathrm{l}$ substrate. Biochemical studies of isolated rat islets showed that high- $\mathrm{K}_{m}$ glycolysis is at least partly the result of high- $\mathrm{K}_{\mathrm{m}}$ hexokinase IV (glucokinase) which catalyses around $50 \%$ of overall glucose phosphorylation in extracts of whole islets (reviewed in [15]). The pivotal role of glucokinase in glucose homeostasis was recently underlined by three in vivo models in which the normal glucokinase gene was disrupted in the mouse genome by homologous recombination with a mutated gene [16-18]. In each of these models the heterozygous mice were mildly diabetic, while the homozygous animals with the null mutation died soon after birth. In the heterozygous animals a beta-cell secretion defect was observed, since the dose-response curve of glucose-induced insulin release was shifted to the right. In order to avoid disturbed postprandial hepatic glucose disposition, one of the knockout models was designed by deletion of the beta-cell-specific exon of the glucokinase gene, thus preserving liver 
glucokinase expression [18]. These animals were abnormal in insulin secretion as well. The mouse models beautifully mimicked the diabetic state and impaired glucose sensing observed in maturity-onset diabetes of the young (MODY) patients with mutations in the glucokinase gene $[19,20]$.

\section{G L UT2 as a candidate glucose sensor protein in} rodent models

While glucokinase was shown to be rate-limiting for overall glucose metabolism [15], glucose transport in rat islet cells was found to be an extremely rapid process, equilibrating intracellular and extracellular glucose concentrations within seconds [21]. The molecular basis for this rapid transport in rodent islets was clarified with the cloning of the rat liver facilitative glucose transporter isoform GLUT2 which is selectively expressed in liver, islet beta cells and the basolateral membranes of kidney tubular epithelial cells and intestinal mucosa cells [1]. Because the transporter has a high- $\mathrm{K}_{\mathrm{m}}$ for glucose (around $15 \mathrm{mmol} / \mathrm{l}$ ) G LUT 2 was proposed to be a glucose sensor protein in beta cells in concert with glucokinase [1]. Indirect evidence for this concept was found by observing a parallel reduction of islet GLUT2 expression and loss of glucose-induced insulin release in Z ucker diabetic rats (ZDR ), a model in which the male animals become obese, insulin resistant and overtly diabetic between week 7 and 9 after birth, while the obese and insulin resistant female animals remain non-diabetic [22]. In the male animals, the severity of diabetes was strongly correlated to the number of GLUT2-immunoreactive beta cells, while liver G L UT 2 was not affected to the same extent [22]. In the female ZDR animals a 24-day treatment with $0.2-0.4 \mathrm{mg} \cdot \mathrm{kg}^{-1} \cdot$ day $^{-1}$ dexamethazone induced diabetes, which was accompanied by a loss of glucose-induced (but not arginine-induced) insulin release [23]. The animals had down regulated high- $\mathrm{K}_{\mathrm{m}}$ glucose uptake in islet cells to about $50 \%$ of the normal value, which correlated well with the observed decrease [23] in the number of G LUT2 immunoreactive beta cells (from 100 to $24 \%$ ). Since total islet G L U T 2 protein decreased by only $30 \%$, while pancreatic GLUT2 mRNA even increased in the Zucker diabetic animals [23], it was suggested that: (i) hyperglycaemia increases beta-cell G L U T2 transcription; (ii) down regulation of GLUT2 expression is mediated at the (post)translational level and (iii) not all beta cells are affected to the same degree by loss of GLUT2 expression [24]. The first hypothesis is further supported by observations that glucose increases beta-cell GLU T2 transcription both in cultured islets [25] and in glucose-infused rats [26]. The idea of heterogeneity in beta-cell G LU T 2 expression is in agreement with the observation that rat beta cells are heterogeneous in glucose-induced proinsulin biosynthesis [27]. However, when beta-cell subsets were flow sorted on the basis of low and high NA DPH autofluorescence after incubation in $7.5 \mathrm{mmol} / /$ glucose [28], no differences were observed in terms of glucose uptake, G L U T2 mR N A level and protein abundance [29], suggesting that this issue needs further investigation in the Zucker model.

Transplantation of non-diabetic G LU T2-positive islets into diabetic recipients has suggested that loss of G L U T2 expression in islets can be experimentally induced by the diabetic environment [30]. In the $\mathrm{db}$ mouse, an animal model of diabetes and obesity with a mutation in the leptin receptor gene [31], transplantation of GLUT2-positive $\mathrm{db} /$ + islets under the kidney capsule of $\mathrm{db} / \mathrm{db}$ animals led to the disappearance of G LUT2 protein from islet beta cells, while kidney G LUT 2 remained unaltered [30]. Conversely, transplantation of $\mathrm{db} / \mathrm{db}$ GLUT2-negative islets into $\mathrm{db} /$ + recipients resulted in the reappearance of the transporter in the transplanted islets, showing that betacell loss of GLUT2 in diabetic animals is reversible. $M$ oreover, the reversibility of the diabetic down regulation was not specific for the $\mathrm{db}$ mutation since it was also observed in the model of streptozotocin-induced diabetes [30].

D espite the fact that the transplantation studies described here indicate that down regulation of islet GLUT2 is the consequence rather than the cause of the diabetic condition, it can be argued that the observed reduction of GLUT2 in rat beta cells impairs glucose sensing, thereby contributing to the beta-cell failure in diabetes. However, it is difficult to accept the idea that 50 to $80 \%$ reduction of GLUT2-mediated glucose transport can be responsible for decreased glucose sensitivity and glucose responsiveness of rodent beta cells. Indeed, kinetic measurements in rat islets [21] or pure beta cells [29] show that transport can provide a metabolic flux that is two orders of magnitude higher than the actual glycolytic rate in these cells, suggesting that down regulation of GLUT2 in rat beta cells should be at least $95 \%$ in order to impair glucose-induced insulin release.

Manipulation of beta-cell GLUT2 expression in transgenic mouse models or via in vitro gene transfer technology has generated data both in support and against the concept that moderate reduction in GLUT2 may cause a glucose sensing defect. Valera et al. [32] showed that expression of an antisense G L U T 2 transgene controlled by the rat insulin-1 promoter (RIP-1) in mice leads to $80 \%$ reduction of islet GLUT2 mRNA [32]. The animals became diabetic and had lower plasma insulin levels than control mice. Islets isolated from the transgenic mice exhibited a severely blunted dose-response curve for glucose-induced insulin release with reduced secretory capacity rather than decreased sensitivity for glucose. 
Unless beta-cell heterogeneity is considered, this change in the dose-response curve of glucose-induced insulin release seems not fully compatible with the hypothesis that reduced transport via GLUT2 is responsible for the secretory defect. In vitro transfection experiments of GLUT2 constructs into insulin secreting cell lines have generated diverging results, probably depending on the particular cell line that was used, the efficacy of gene transfer and the cell culture condition. In A tT-20ins cells, an anterior pituitary cell line engineered to express the human proinsulin gene [33] and which has glucokinase activity [34], insulin release became weakly glucose-responsive (twofold stimulation) when stably transfected with G LU T2 cD NA , while glucose transport capacity increased 35-50 fold [35]. G lucose stimulation in this model was maximal at $10 \mu \mathrm{mol} / \mathrm{l}$ substrate, while the $\mathrm{K}_{\mathrm{m}}$ for glucose uptake was 17-25 mmol//; this was explained by the fact that $90 \%$ of total glucose phosphorylation was catalysed by low- $\mathrm{K}_{m}$ hexokinases [35]. Interestingly, (i) transfection with G LU T1 had no effect on glucose-induced insulin release in A tT20ins, and (ii) neither in GLUT1- nor in GLUT2 transfected cell lines was glycolysis accelerated, suggesting that GLUT2-mediated glucose sensing in these cells occurred via a metabolism-independent mechanism [36]. The rat insulinoma cell line RIN 1046-38 gradually loses its capacity for glucose sensing with increasing passage number [37]. Transfection of the GLUT2 gene into the cells resulted in stable upregulation of GLUT2 mR NA and protein while 3OM G uptake increased 25-fold, and insulin secretion became responsive (twofold stimulation) to $50 \mu \mathrm{mol} / \mathrm{l}$ glucose [37]. Interestingly, the GLUT2 transfected cells expressed four times more glucokinase than the control cells, indicating that G LUT2 expression was somehow linked to glucokinase enzyme activity in these cells. The concern for possible clonal selection during the increase in passage number was considered by obtaining similar - though more transient and less pronounced - effects after adenovirus-mediated transfer of the GLUT2 gene in the cells [37], a highly efficient transfer technique. In contrast with the previous study, no link between G L UT2 expression and glucokinase activity was observed by I shihara et al. [38] who transfected the human GLUT2 gene in the murine insulinoma cell line M I N 6. Stably transformed cells exhibited twofold higher rates of 3-O M G uptake but no change in glucokinase activity or glycolytic flux. A major difference between this study and that of Ferber et al. [37] is that the untransfected M IN 6 cell line has a higher glucokinase/ hexokinase ratio (approximately 10 ) than that observed in most other cell lines, including R IN 104638. Second, the upregulation of G LUT 2 in the M IN 6 cells was more modest than in the R IN 1046- 38 cells. Finally, since human G L U T 2 was used in murine cells [38], while rat GLUT2 was hyperexpressed in an isogenic system [37], it is possible that species differences in protein sequence are important for proteinprotein surface interactions between GLUT2, glucokinase or other proteins.

The idea that GLUT2 and glucokinase need to be co-expressed in the same cell for proper functioning of a metabolic glucose sensor may be challenged, however, by recent experiments in rat purified glucagon-producing cells [6, 39]. Pure alpha cells are regulated by glucose in the millimolar concentration range in an opposite way to beta cells, i.e. suppression by high glucose and high rates of glucagon release at low glucose [40]. While glucose transport of alpha cells is slower than in rat beta cells [41], the process is not rate-limiting for overall glycolysis in the cells. Furthermore, glycolysis in alpha cells exhibits the same high- $\mathrm{K}_{\mathrm{m}}$ for glucose and proceeds at comparable absolute rates when compared to glycolytic flux in pure beta cells [39]. The differences in glucose transport could be explained by the fact that alpha cells do not express the high capacity transporter G L UT 2 but only G LU T1, while transport in rat beta cells is dominated by GL U T2 [39]. The high- $\mathrm{K}_{m}$ glucose utilisation in al pha cells was explained by the observation that these cells express glucokinase in quantities that render the enzyme rate-limiting for overall glucose metabolism, in a manner analogous to beta cells [6]. Therefore, since alpha cells do not express the GLUT2 gene, it can be suggested that glucose sensing in endocrine cells of the rat does not necessarily require the co-expression of G L U T2 and glucokinase.

D ifference in G L UT 2 expression in human compared to rodent beta cells

Contrasting with the wealth of information concerning the expression and function of G LUT2 in rodent islets and its disturbance in animal models of NIDDM, data on the presence and function of GLUT2 in human beta cells are scarce. Two recent studies $[4,5]$ reported a very low G L U T2 expression in human islet cells when compared to human liver or rat islet cells. The first suggested that transporters other than G L U T 2 mediate glucose uptake in human islet cells [4], and the second observed no decrease in GLUT2 mR NA or protein in islets isolated from donor organs of NIDDM patients [5]. These data suggest that the rodent islet physiology and some animal models of NIDDM may not be extrapolated to the human situation.

The study of D e Vos et al. [4] was conducted on 23 different human islet cell preparations obtained within the framework of a E uropean concerted program for the implantation of beta-cell grafts in IDDM [42]. B oth the viability of the cells $(>95 \%)$ and the beta-cell enrichment ( $52 \pm 4 \%$ ) were comparable to 


\section{$\begin{array}{llllll}1 & 2 & 3 & 4 & 5 & 6\end{array}$}

GLUT 2

Glucokinase

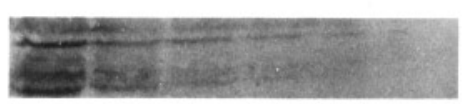

$\beta$-actin

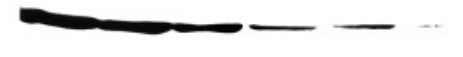

GLUT 2

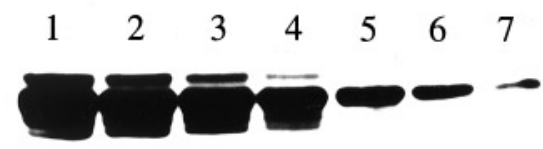

Glucokinase

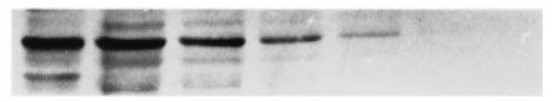

$\beta$-actin

Fig. 1. Human and rat beta cells differ in GLUT2 but not in glucokinase gene expression. I mmunoblots of protein extracts from isolated human islet cells (upper panel) and rat islet cells (lower panel) assessing relative abundance of G LU T 2 protein, glucokinase and beta actin. U ndiluted extract (lane 1 ) contains protein from $5 \times 10^{5}$ islet cells (approximately $25 \mu \mathrm{g}$ protein), whereas lanes 2-7 were loaded with extract diluted in sample buffer 2-, 4-, 8-, 16-, 32- and 64-fold before electrophoresis. In a second experiment rat islet cell GLUT2 was still detected in a 128-fold diluted sample. Reproduced from The Journal of Clinical Investigation (1995) 96:2489-2495, copyright permission of The A merican Society for Clinical Investigation

values routinely obtained in dissociated rat islet cell preparations which were used as a reference standard. U sing human- and rat-specific CDNA probes and antibodies, a difference in G LU T 2 expression level in human compared to rat islet cells of two orders of magnitude or more was observed. In Northern blots weak autoradiographic signals were only obtained after prolonged exposure, while Western blots were negative with protein extracted from $5 \times 10^{5}$ human islet cells (approximately $25 \mu \mathrm{g}$ of protein). Stepwise dilution series of rat and human islet cell protein extracts (Fig.1) allowed us to estimate that human beta cells contain at least 64 -fold less G L U T 2 protein than rat beta cells, while islet glucokinase appeared equally abundant in both species. The difference between human and rat islet G LUT2 abundance also contrasts with liver GLUT2 expression, where protein abundance appears to be similar between these two species (Fig. 2). The low expression of human GLUT2 in islets could not be ascribed to differences in the islet isolation procedure, culture conditions or the clinical history of the pancreatic donors, since identical results were obtained by immunostaining of human liver and pancreatic biopsies, i.e. negative immunostaining in pancreas and strong membrane immunostaining in liver [4].

\section{Human liver protein $(\mu \mathrm{g})$}

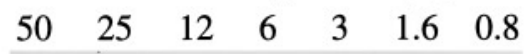

GLUT2

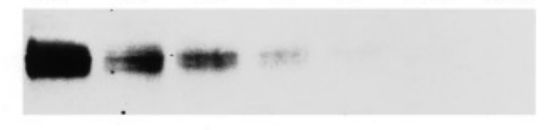

Rat liver protein $(\mu \mathrm{g})$

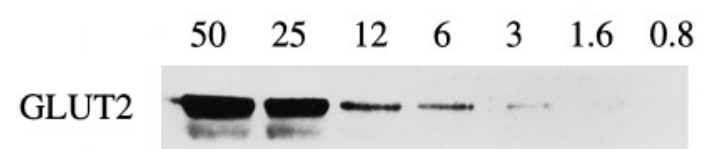

Fig. 2. H uman and rat liver exhibit comparable abundance of GLUT 2 protein. I mmunoblots of protein extracts from human liver (upper panel) and rat liver (lower panel) using speciesspecific antisera GLUT2 and twostep dilution of extract in sample buffer before electrophoresis. Without prepurification of total liver protein, GLUT2 immunoreactivity was detectable after blotting $3 \mu \mathrm{g}$ of human liver protein and $1.6 \mu \mathrm{g}$ of rat liver protein

Ferrer et al. [5] studied human islets from 11 nondiabetic and 4 diabetic organ donors. A Iso in this study mRNA abundance was close to the detection limit of Northern blotting, and required competitive reverse transcriptase-polymerase chain reaction (RT-PCR ) for accurate measurements. Furthermore, GLUT2 protein detection required $100 \mu \mathrm{g}$ of human islet cell protein per lane, loading of $20 \mu \mathrm{g}$ protein giving negative results. In agreement with $D$ e Vos et al. [4] GLUT2 immunostaining of human - but not rat - pancreatic cryosections was negative. B oth the amplified GLUT2 CD N A abundance and the immunoreactive protein abundance were similar when comparing islets from diabetic and non-diabetic donors [5].

Thus, on a total of 34 different human islet cell preparations from non-diabetic donors, G LUT 2 expression appears much lower, possibly by a factor of 100 or more, than that in rodent islets. This idea is in good agreement with incidental reports of a very low abundance of GLUT2 mRNA in human islet extracts, while abundant GLUT2 transcripts were reported in human liver $[43,44]$. Considering these results, it may be surprising that glucose sensing in isolated human islets appears to be quite normal [45]. Is the low G LUT 2 level sufficient to allow human beta cells to sense glucose or is another isoform of the facilitative glucose transporter family required?

Can G L UT2 function be replaced by another glucose transporter?

In rat liver parenchymal cells [46], pancreatic islets $[25,47]$, and purified beta-cell preparations $[29,39]$ GLUT2 is not the only glucose transporter that is expressed, since GLUTImRNA and protein are 
detected in parallel. These results are not entirely unexpected, since GLUT1, the low- $\mathrm{K}_{\mathrm{m}}$ transporter that was originally described in erythrocytes and brain [48], seems to be ubiquitously expressed and is believed to be responsible for basal glucose transport in most cells [49]. In hepatocytes co-expression of GLUT1 and GLUT2 appears restricted to a very limited zone of the liver lobules [46], which is in agreement with the concept of metabolic heterogeneity of liver tissue [50]. H owever, no heterogeneity in G LUT 1 expression was observed in beta-cell subsets with different sensitivity to glucose [29]. M oreover, kinetic analysis indicates that the relative activity of GLUT 1 in rat beta cells is low when compared to that of GLUT2. In unpurified islet cell preparations [51], the low- $K_{m}$ component of 3-O M G transport can be detected, but this component segregates with the non-beta-cell preparation after flow sorting of islet cells [39]. U pregulation of GLUT1, either in neonatal islet cells [52] or in M IN 6 cells [53] had little effect on glucose sensing, probably because of the dominating influence of GLUT2. So the role of GLUT1 in rodent beta cells with high GLUT2 expression seems to be of minor relevance for glucose sensing.

Studies in human islet cells again deviate markedly from the data obtained in rodent models. Expression of G LUT 1 and G LUT 3 was detected in human beta cells, both at $\mathrm{mRNA}$ and protein level [4]. M oreover, 3-O M G transport in human islet cells exhibited a low- $\mathrm{K}_{\mathrm{m}}$ for substrate $(3 \mathrm{mmol} / \mathrm{l})$ which is compatible with the known transport kinetics of GLUT1 and/or GLUT3, but not with that of GLUT2. Whereas transport velocity in human islet cells was only $10 \%$ of that observed in rat islet cells, the rate of glycolysis or glucokinase activity was the same in both species [4]. Thus, it appears that transport function - carried out by G LUT 2 in rat beta cells - is substituted by G LUT 1 and/or G LUT 3 in human beta cells.

It can be postulated on basis of these observations that the $K_{m}$ of the glucose transporter does not really matter for the time required to equilibrate intracellular and extracellular glucose concentrations in beta cells. Such conditions can only be met as long as transport velocity largely exceeds catalytic capacity of glucokinase, the rate-limiting enzyme of glycolysis. Computer modelling predicted that transporters with $\mathrm{K}_{\mathrm{m}}$ values of either 1.5 or $17 \mathrm{mmol} / \mathrm{l}$ can both generate increments in high- $\mathrm{K}_{\mathrm{m}}$ glucose phosphorylation when extracellular glucose increased from 6 to $15 \mathrm{mmol} / \mathrm{l}$ [54]. This theoretical model was supported by experimental data in X enopus oocytes injected with glucokinase $\mathrm{mRNA}$ and either GLUT 2 or GLUT 3 mR NA : injection of GLUT 2 or GLUT3 mRNA had the same stimulatory effect upon high- $K_{m}$ glucose phosphorylation by glucokinase [55]. Thus, both GLUT1 and GLUT3, low- $\mathrm{K}_{\mathrm{m}}$ transporters expressed in many human tissues [49], may kinetically substitute for G LUT2 in human islet cells. It remains to be examined, however, if the low abundance of GLUT2 in human pancreas is required for an isoform-specific, non-transport function of the protein.

\section{Implications for human diabetes}

The putative pathophysiological implication of the low human beta-cell G L U T2 expression with respect to the development of human diabetes remains unclear. In the four NIDDM subjects from whom pancreatic islets were studied postmortem [5] no decrease in GLUT2 abundance was observed. Since NIDDM is a polygenic and multifactorial disorder, the low number of patients in this study does not exclude a role for GLUT2 defects in subgroups of patients. Polymorphism in the human G L U T2 gene has been described, but no correlation with NIDDM was observed, either in association studies or in linkage analysis [56, 57]. Interestingly, in one patient with gestational diabetes heterozygosity for a GLUT2 Val197 $\rightarrow$ lle missense mutation was detected; the functional consequence of this mutation - assessed by expression of the mRNA in oocytes - was severe in terms of 3-O M G transport [58]. The described mutation appears to be rare, because it has not yet been found in other diabetic patients.

The interspecies differences in G L U T 2 expression may explain - at least in part - the major difference in sensitivity of human and rat beta cells for the cytotoxic action of streptozotocin and alloxan [59]. Both streptozotocin and alloxan are unstable molecules, so that cells sensitive to their cytotoxic action are expected to exhibit high transport rates. Streptozotocin, a nitroso urea-derivative of glucose, has been reported to be more cytotoxic for both RIN - and A tT20ins-cells when these cells were transfected with GLUT2 cDNA as compared to cells transfected with GLUT1 CDNA [60], suggesting that uptake of the short-living toxin is a GLUT2-specific process. Furthermore, the resistance (both in vivo and in vitro) of human beta-cells to the cytotoxic action of alloxan [59] has been correlated to uptake kinetics of the toxin, which was 10 times slower in human islet cells than in rat islet cells [4]. Finally, in rat cells, alloxan uptake was competitively inhibited by unlabelled 3-OM G but not by L-glucose, indicating that the agent indeed enters the cells via a glucose transporter [4]. While it is conceivable that low human islet GLUT2 expression contributes to low beta-cell toxicity of streptozotocin and alloxan in man, it should be mentioned that other mechanisms such as expression of heat shock proteins, free radical scavenging enzymes [61] or other repair genes can be responsible as well. 


\section{Conclusions and prospects}

A t this moment no firm basis for a role of G L U T 2 in human diabetes has been found, except for a single case presenting with a heterozygous Val197 $\rightarrow$ l le mutation in gestational diabetes which regressed spontaneously [58]. I $f$ this mutation can be observed in other patients, it would be of great importance to study the natural history of the disease, in order to find out whether the prime defect is impaired hepatic glucose disposal, beta-cell glucose-insensitivity or a combination of both. If such a beta-cell defect exists before development of hyperglycaemia, this would be evidence for the idea that G LUT 2 is important for glucose sensing in human islets. Since transport function in normal human islet cells appears largely mediated by the low- $\mathrm{K}_{\mathrm{m}}$ transporters G LUT 1 and/or G LUT3, it can be speculated that the low GLUT2 expression plays a role distinct from glucose transport but more directly related to exocytosis. A study of GLUT2 ultrastructural localisation in rat pancreas [62] has indicated that the transporter is preferentially present in microvillous domains of the beta-cell plasma membrane. A nalogous to the erythrocyte $\mathrm{Cl}^{-} / \mathrm{HCO}_{3}{ }^{-}$transporter which binds ankyrin and hence organises the membrane-bound cytoskeleton [63], it can be speculated that G LUT2 plays a so far unrecognised role in membrane organisation, a process that is central to exocytosis. In this respect, the fact that rat GLUT2 can be phosphorylated by protein kinase $A$, without causing major changes in its transport kinetics [64], should be kept in mind, because elevation of rat beta-cell CAMP has on the one hand major effects upon glucose-induced insulin secretion [65], but on the other hand no significant effect upon the rate of glucose metabolism [41]. Furthermore, again analogous to the aminoterminal end of the erythrocyte anion channel [63], G LU T2 may be responsible for the anchoring of certain glycolytic enzymes, thereby concentrating possible metabolic signals close to target site(s) involved in exocytosis. In this context, it should be mentioned that this feature can be shared by other G L U T isoforms present in human beta cells, since the human erythrocyte glucose transporter was reported to bind the glycolytic enzyme glyceraldehyde 3-phosphate dehydrogenase in an A TP-dependent reversible manner [66]. Site-directed mutagenesis of rat, mouse and human G L UT 2 and novel functional tests are required to indicate which residues of the transporter protein are involved in these hypothetical non-transport functions of GLUT2. Expression experiments of mutated human GLUT2 in rodent cell lines may be hampered by species differences in protein sequence which may be relevant for non-covalent protein-protein interactions. Future research in this direction would therefore benefit from experiments using either primary cultures of human beta cells or a human beta-cell line with well-preserved glucose sensing properties. Such in vitro models may increase our understanding of the differences and similarities in glucose sensing by rodent and human islets, for instance by measuring the expression of the human homologues of the murine 180 and 90 kD a GT-II binding transcription factors, which seem responsible for islet-specific G L U T2 expression [67]. A human glucose-responsive beta-cell line should also generate new data answering the question of which level of GLUT2 expression of the endocrine pancreas is required for glucose-induced insulin secretion in man.

A cknowledgements. The author is grateful to $\mathrm{H}$. H eimberg, A . D e Vos, E. Q uartier, K. M oens, P. H uypens, L. Bouwens, D. Pipeleers, E. Van Schaftingen and B. Thorens, for their valuable contributions to work discussed in this paper and to A.Gielen for secretarial help. H. Heimberg, D. Eizirik, and $D$. Pipeleers are thanked for reading the manuscript and giving their comments. Work of the author has been supported by grants from the B elgian $F$ und for M edical Scientific R esearch (FGWO grants 3.0127 .93 and 9.0011.95), the Belgian Programme on Interuniversity Poles of $A$ ttraction initiated by the Belgian State (IUAP 15), and the Research Council of the $\checkmark$ rije U niversiteit Brussel.

\section{References}

1. Thorens B, Sarkar HK, K aback HR, Lodish HF (1988) Cloning and functional expression in bacteria of a novel glucose transporter present in liver, intestine, kidney, and $\beta$-pancreatic islet cells. Cell 55: 281-290

2. Thorens B (1992) Molecular and cellular physiology of GLUT-2, a high- $K_{m}$ facilitated diffusion glucose transporter. International R eview of Cytology 137A :209238

3. Unger RH (1991) Diabetic hyperglycaemia: link to impaired glucose transport in pancreatic $\beta$ cells. Science 251: 1200- 1205

4. De Vos A, Heimberg H, Quartier E et al. (1995) Human and rat beta cells differ in glucose transporter but not in glucokinase gene expression. J Clin Invest 96: 24892495

5. Ferrer J, B enito C, G omis R (1995) Pancreatic islet G L U T2 glucose transporter $\mathrm{mRNA}$ and protein expression in humans with and without NID D M . D iabetes 44: 1369-1374

6. H eimberg H, D e Vos A, M oens K et al. (1996) The glucose sensor protein glucokinase is expressed in glucagon-producing alpha cells. Proc Natl A cad Sci U SA 93: 7036-7041

7. M acD onald MJ (1990) Elusive proximal signals of $\beta$-cells for insulin secretion. D iabetes 39: 1461-1466

8. N ewgard CB, M cG arry DJ (1995) M etabolic coupling factors in pancreatic $\beta$-cell signal transduction. A nn R ev Biochem 64: 689-719

9. Grodsky GM, Batts $A A$, B ennett $L L, V$ cella $C, M c W i l-$ liams N B , Smith D F (1963) E ffects of carbohydrates on secretion of insulin from isolated rat pancreas. A m J Physiol 205: 638-644

10. H ellerström C (1967) E ffects of carbohydrates on the oxygen consumption of isolated pancreatic islets of mice. Endocrinology 81: 105-112

11. A shcroft SJ H (1980) Glucoreceptor mechanisms and the control of insulin release and biosynthesis. Diabetologia 18: 5-15 
12. Coore HG, Randle PJ (1963) Block of insulin secretion from the pancreas by d-mannoheptulose. Nature 197: 1264-1266

13. A shcroft FM , H arrison DE, A shcroft SJ H (1984) G lucose induces closure of single potassium channels in isolated rat pancreatic $\beta$-cells. $N$ ature $312: 446-448$

14. M alaisse WJ, Sener A, H erchuelz A , H utton J C (1979) Insulin release: the fuel hypothesis. M etabolism 28: 373-386

15. M atschinsky F, Liang Y, K esavan P et al. (1993) G lucokinase as pancreatic $\beta$ cell glucose sensor and diabetes gene. J Clin Invest 92: 2092-2098

16. Grupe A, H ultgren B, R yan A, M a Y H, B auer M, Stewart TA (1995) Transgenic knockouts reveal a critical requirement for pancreatic $\beta$ cell glucokinase in maintaining glucose homeostasis. Cell 83: 69-78

17. Bali D, Svetlanov A, Lee HW et al. (1995) A nimal model for maturity-onset diabetes of the young generated by disruption of the mouse glucokinase gene. J $\mathrm{B}$ iol Chem 270: 21464-21467

18. Terauchi Y, Sakura H, Y asuda K et al. (1995) Pancreatic $\beta$ cell-specific targeted disruption of glucokinase gene. J Biol Chem 270: 30253-30256

19. Vionnet N, Stoffel M, Takeda J et al. (1992) N onsense mutation in the glucokinase gene causes early-onset non-insulin-dependent diabetes mellitus. N ature 356: 721-722

20. Velho G, Froguel P, Clement K et al. (1992) Primary pancreatic beta-cell secretory defect caused by mutations in glucokinase gene in kindreds of maturity onset diabetes of the young. Lancet 340: 444-448

21. Hellman B, Sehlin J, Täljedal IB (1971) E vidence for mediated transport of glucose in mammalian pancreatic $\beta$-cells. B iochim B iophys A cta 241: 147-154

22. Johnson J H, O gawa A , Chen L et al. (1990) U nderexpression of $\beta$ cell high $\mathrm{Km}$ glucose transporters in noninsulindependent diabetes. Science 250: 546-549

23. O gawa A, Johnson J H, O hneda M et al. (1992) R oles of insulin resistance and $\beta$-cell dysfunction in dexamethasoneinduced diabetes. J Clin I nvest 90: 497-504

24. Ohneda M, Johnson JH, Inman LR, Unger RH (1993) GLUT-2 function in glucose-unresponsive $\beta$ cells of dexamethasone-induced diabetes in rats. J Clin Invest 92: 1950-1956

25. Tal $M$, Liang $H$, Najafi $H$, Lodish HF, Matschinsky FM (1992) Expression and function of G LUT-1 and GLUT-2 glucose transporter isoforms in cells of cultured rat pancreatic islets. J Biol Chem 267: 17241-17247

26. Chen L, A lam T, Johnson J H, H ughes S, N ewgard CB, U nger RH (1990) Regulation of $\beta$-cell glucose transporter gene expression. Proc N atl A cad Sci U SA 87: 4088-4092

27. Schuit FC, In't Veld PA, Pipeleers DG (1988) Glucose stimulates proinsulin biosynthesis by a dose-dependent recruitment of pancreatic beta cells. Proc Natl A cad Sci USA 85: 3865-3869

28. K iekens R, In't Veld P, M ahler T, Schuit F, Van de Winkel $M$, Pipeleers D (1992) Differences in glucose recognition by individual rat pancreatic B-cells are associated with intercellular differences in glucose-induced biosynthetic activity. J Clin Invest 89: 117-125

29. H eimberg H, De Vos A, Vandercammen A, Van Schaftingen $E$, Pipeleers D, Schuit $F$ (1993) H eterogeneity in glucose sensitivity among pancreatic $\beta$-cells is correlated to differences in glucose phosphorylation rather than glucose transport. E M BO J 12: 2873-2879

30. Thorens B, Wu Y J, L eahy J L, Weir GC (1992) The loss of G LUT 2 expression by glucose-unresponsive $\beta$ cells of $\mathrm{db} /$ $\mathrm{db}$ mice is reversible and is induced by the diabetic environment. J Clin Invest 90: 77-85
31. Chen H, Charlat O, Tartaglia LA et al. (1996) Evidence that the diabetes gene encodes the leptin receptor: identification of a mutation in the leptin receptor gene in $\mathrm{db} / \mathrm{db}$ mice. Cell 84: 491-495

32. Valera A , Solanes G, Fernandez-A Ivarez J et al. (1994) E xpression of G LUT-2 antisense R NA in $\beta$ cells of transgenic mice leads to diabetes. J B iol Chem 269: 28543-28546

33. M oore H P, Walker M D, Lee F, K elly R B (1983) Expressing a human proinsulin CDNA in a mouse ACTH-secreting cell. Intracellular storage, proteolytic processing, and secretion on stimulation. Cell 35: 531-538

34. Hughes SD, Q uaade C, M ilburn J L, Cassidy L, N ewgard CB (1991) Expression of normal and novel glucokinase mR NA s in anterior pituitary and islet cells. J Biol Chem 266: 4521-4530

35. H ughesSD, J ohnson J H, Q uaade C, N ewgard CB (1992) E ngineering of glucose-stimulated insul in secretion and biosynthesis in non-islet cells. Proc N atl A cad Sci U SA 89: 688-692

36. H ughes SD, Q uaade C, J ohnson J H , Ferber S, N ewgard CB (1993) Transfection of A tT-20 ins cells with G L U T-2 but not GLUT-1 confers glucose-stimulated insulin secretion. J Biol Chem 268: 15205-15212

37. Ferber S, B eltrandelRio H, Johnson JH et al. (1994) GLUT-2 gene transfer into insulinoma cells confers both low and high affinity glucose-stimulated insulin release. J Biom Chem 269: 11523-11529

38. I shihara H, A sano T, Tsukuda K et al. (1995) Human G L U T-2 overexpression does not affect glucose-stimulated insulin secretion in M I N 6 cells. A mJ Physiol 269:E 897-E 902

39. H eimberg H, D e Vos A, Pipeleers D, Thorens B, Schuit F (1995) Differences in glucose transporter gene expression between rat pancreatic $\alpha$ - and $\beta$-cells are correlated to differences in glucose transport but not in glucose utilisation. J Biol Chem 270: 8971-8975

40. Pipeleers D G, Schuit FC, Van Schravendijk CFH, Van De Winkel M (1985) Interplay of nutrients and hormones in the regulation of glucagon release. Endocrinology 117: 817-823

41. G orus F, M alaisse WJ, Pipeleers D (1984) Differences in glucose handling by pancreatic A - and B-cells. J Biol Chem 259: 1196-1200

42. Pipeleers D (1994) Treatment of diabetes by islet cell transplantation. In: Baya C (ed) Biomedical and health research. vol 3 A dvances in medical biology. IO S Press, A msterdam, pp 185-197

43. Permutt MA, Koranyi L, Keller K, Lacy PE, Scharp DW, M ueckler $M$ (1989) Cloning and functional expression of a human pancreatic islet glucose-transporter CDNA. Proc $\mathrm{N}$ atl A cad Sci U SA 86: 8688-8692

44. Seino $Y$, Yamamoto $T$, I noue K et al. (1993) A bnormal facilitative glucose transporter gene expression in human islet cell tumors. J Clin Endocrinol M etab 76: 75-78

45. L ing Z, Pipeleers D (1996) Prolonged exposure of human $\beta$ cells to elevated glucose levels results in sustained cellular activation leading to a loss of glucose regulation. J Clin Invest In press ( $D$ ecember I ssue)

46. Tal M, Schneider DL, Thorens B, Lodish HF (1990) Restricted expression of the erythroid/brain glucose transporter isoform to perivenous hepatocytes in rats. J Clin Invest 86: 986-992

47. $Y$ asuda $K$, $Y$ amada $Y$, Inagaki $N$ et al. (1992) Expression of G L U T 1 and G L U T 2 glucose transporter isoforms in rat islets of $L$ angerhans and their regulation by glucose. $D$ iabetes 41: 76-81

48. M ueckler M, Caruso C, B aldwin SA et al. (1985) Sequence and structure of a human glucose transporter. Science 229: 941-945 
49. M ueckler M (1994) Facilitative glucose transporters. E ur J Biochem 219: 713-725

50. Jungermann K, K atz N (1989) Functional specialization of different hepatocyte populations. Physiol R ev 69: 708-764

51. Johnson J H, N ewgard CB , M ilburn J L, L odish H F, Thorens $B$ (1990) The high $\mathrm{Km}$ glucose transporter of islets of $\mathrm{L}$ angerhans is functionally similar to the low affinity transporter of liver and has identical primary sequence. J Biol Chem 265: 6548-6551

52. G erman M S (1993) G lucose sensing in pancreatic islet beta cells: the key role of glucokinase and the glycolytic intermediates. Proc Natl A cad Sci U SA 90: 1781-1785

53. I shihara H, A sano T, T sukuda K et al. (1994) O verexpression of hexokinase I but not G L U T 1 glucose transporter alters concentration dependence of glucose-stimulated insulin secretion in pancreatic $\beta$-cell line MIN6. J Biol Chem 269: 3081-3087

54. L achaal M, Spangler RA, Jung CY (1993) High $K_{m}$ of G L U T-2 glucose transporter does not explain its role in insulin secretion. A m J Physiol 265:E 914-E 919

55. M orita H, Yano Y, Niswender K D et al. (1994) Coexpression of glucose transporters and glucokinase in $X$ enopus oocytes indicates that both glucose transport and phosphorylation determine glucose utilization. J Clin Invest 94: 1373-1382

56. Patel P, Bell GI, Cook JTE, Turner RC, Wainscoat JS (1991) M ultiple restriction fragment length polymorphisms at the G L U T 2 locus: G L U T 2 haplotypes for genetic analysis of type 2 (non-insulin-dependent) diabetes mellitus. D iabetologia 34: 817-821

57. Elbein SC, Hoffman MD, Matsutani A, Permutt MA (1992) Linkage analysis of GLUT1 (H epG 2) and GLUT2 (liver/islet) genes in familial NIDD M. Diabetes 41: 16601667

58. M ueckler $M, K$ ruse $M$, Strube $M, R$ iggs $A C$, Chiu $K C$, Permutt MA (1994) A mutation in the Glut2 glucose transporter gene of a diabetic patient abolishes transport activity. J Biol Chem 269: 17765-17767

59. E izirik D L, Pipeleers D G, Ling Z, Welsh N, H ellerström C, A ndersson A (1994) M ajor species differences between humans and rodents in the susceptibility to pancreatic ß-cell injury. Proc N atl A cad Sci U SA 91: 9253-9256

60. Schnedl WJ, Ferber S, Johnson JH, Newgard CB (1994) STZ transport and cytotoxicity. Specific enhancement in G L U T 2-expressing cells. D iabetes 43: 1326-1333

61. Welsh N, M argulis B, Borg LA H et al. (1995) Differences in the expression of heat-shock proteins and antioxidant enzymes between human and rodent pancreatic islets: implications for the pathogenesis of insulin-dependent diabetes mellitus. M olecular M edicine 1: 806-820

62. Orci L, Thorens B, R avazzola M, L odish H F (1989) L ocalization of the pancreatic beta cell glucose transporter to specific plasma membrane domains. Science 245: 295-297

63. Kopito R R , L odish H F (1985) Primary structure and transmembrane orientation of the murine anion exchange protein. N ature 316: 234-238

64. Thorens B, D ériaz N, B osco D et al. (1996) Protein kinase A -dependent phosphorylation of GLUT2 in pancreatic $ß$ cells. J B iol Chem 271: 8075-8081

65. Pipeleers D G, Schuit FC, In't Veld PA et al. (1985) Interplay of nutrients and hormones in the regulation of insulin release. Endocrinology 117: 824-833

66. L achaal M, Berenski CJ, K im J, Jung CY (1990) A n A TPmodulated specific association of glyceraldehyde-3-phosphate dehydrogenase with human erythrocyte glucose transporter. J B iol Chem 265: 15449-15454

67. B onny C, Thompson N, Nicod P, Waeber G (1995) Pancreatic-specific expression of the glucose transporter type 2 gene: identification of cis-elements and islet-specific transacting factors. M ol E ndocrinol 9: 1413-1426 